\title{
КЛІНІКО-ПСИХОПАТОЛОГІЧНІ ОСОБЛИВОСТІ ПАЦІЄНТІВ 3 ТРАВМАТИЧНИМ УШКОДЖЕННЯМ ОРГАНА ЗОРУ
}

\author{
๑Н. Г. Пшук, О. О. Белов, Н. Г. Мацько \\ Вінницький національний медичний університет імені М. І. Пирогова
}

РЕЗЮМЕ. Проблема втрати зору є однією з актуальних медичних і соціальних проблем.

Мета - дослідити особливості клініко-психопатологічних проявів, асоційованих зі значним погіршенням зору внаслідок травматичного пошкодження зорового аналізатора.

Матеріал і методи. Досліджено особливості психопатологічної симптоматики у 37 чоловіків і 11 жінок зі значною втратою зору внаслідок травматичного пошкодження в динаміці у перші два тижні з моменту травми, через 3 місяці, і 12 місяців після травми з використанням шкал депресії і тривоги M. Hamilton, шкал реактивної та особистісної тривожності C. Spilbergeг та опитувальника SCL-90-R.

Результати. Встановлено поступове значуще $(p<0,01)$ зростання рівня депресивних проявів у динаміці через два тижні, 3 і 12 місяців після травматичної втрати зору як в цілому $((18,5 \pm 2,1)$ балів, $(24,2 \pm 3,7) 6 а л і в,(30,6 \pm 7,0) 6 а л і в)$, так і в розрізі окремих видів депресії; а також тривоги в цілому $((23,4 \pm 4,9)$ балів, $(26,7 \pm 5,7) 6$ балів, $(23,5 \pm 5,0) 6 а л і в)$, психічної і соматичної тривоги.

Реактивна тривожність $є$ високою після травми, зростає протягом перших трьох місяців після неї і поступово знижується в подальшому $((46,1 \pm 10,7)$ балів, $(48,5 \pm 12,0)$ балів, $(41,0 \pm 10,1)$ балів). Рівень особистісної тривожності з часом зростає, максимально у період після 3 місяців $((43,3 \pm 11,4)$ балів, $(47,6 \pm 12,5)$ балів, $(54,6 \pm 14,3) 6 а л і в)$, відображаючи формування стійких патохарактерологічних рис.

У гострий та віддалений періоди після травматичної втрати зору спостерігається значуще зростання показників соматизації, обсесивно-компульсивної симптоматики, міжособистісної сенситивності, депресії, тривожності, ворожості та фобічної тривожності $(p<0,01)$. У чоловіків показники вищі, ніж у жінок, однак статистично значущими ці відмінності є лише для міжособистісної сенситивності та депресії.

Висновки. Тяжка втрата зору травматичного ґенезу супроводжується несприятливими психопатологічними порушеннями, насамперед депресивними і тривожними; виразність психопатологічних феноменів поступово наростає після травми. Тяжкість усіх психопатологічних проявів, асоційованих з травматичним ушкодженням зору тяжкого ступеня, у чоловіків $\epsilon$ більшою, порівняно з жінками.

КлючовІ СлОВА: травматична втрата зору; клініко-психопатологічна феноменологія.

Вступ. Втрата зору є однією з актуальних медичних і соціальних проблем [1-3]. За оцінками ВОО3, у світі налічується 285 млн осіб із порушеннями зору, з них 39 млн сліпих (0,56 \% популяції) і 246 млн слабкозорих (3,5%) [4]. Значне погіршення зору є тяжким психоемоційним стресом, воно супроводжується не лише змінами у психоемоційному стані, а й серйозно впливає на порушення взаємодії індивіда з мікросоціальним оточенням та суспільством. Наслідками погіршення зору $\epsilon$ гострі стресові реакції, формування аграваційно-рентних установок і розвиток непсихотичних психічних розладів [5, 6]. Особливо тяжкими ці несприятливі зміни є при раптовій втраті або раптовому значному погіршенні зору, що викликає значні порушення психічного функціонування [7]. Водночас, ряд питань клініко-психопатологічної феноменології, асоційованої зі значним погіршенням зору, залишаються недостатньо вивченими, що утруднює розробку психокорекційних та психотерапевтичних заходів для цієї категорії пацієнтів.

Мета - дослідити особливості клініко-психопатологічних проявів, асоційованих зі значним погіршенням зору внаслідок травматичного пошкодження зорового аналізатора.

Матеріал і методи дослідження. 3 дотриманням принципів біомедичної етики нами було досліджено особливості психопатологічної симптоматики у 48 пацієнтів (37 чоловіків і 11 жінок), які зазнали значної втрати зору (слабкозорість (low vision) тяжкого ступеня і сліпота (blindness) за MKX-10) внаслідок травматичного пошкодження (побутові травми, нещасні випадки, дорожнотранспортні пригоди, наслідки бойових дій), які отримували лікування в лікувально-профілактичних закладах м. Вінниця та Вінницької області протягом 2013-2018 років. Середній вік хворих склав $(39,6 \pm 12,5)$ років (чоловіків - $(40,2 \pm 12,6)$ років, жінок - $(37,5 \pm 12,9)$ років). Обстеження проводили тричі: у перші два тижні з моменту травми, через 3 місяці, і через 12 місяців після травми.

Клініко-психологічне обстеження проведено з використанням шкал депресії і тривоги М. Hamilton $[8,9]$, шкал реактивної та особистісної тривожності C. Spilbergeг у модифікації Ю. Л. Ханіна [10] та опитувальника Symptom Check List-90-Revised (SCL-90-R) у модифікації Н. В. Тара6ріної [11]. 
Огляди літератури, оригінальні дослідження, погляд на проблему, випадок з практики, короткі повідомлення

Статистичну обробку отриманих даних проводили з використанням непараметричного тесту Манна-Уїтні.

Результати й обговорення. Аналіз показників депресії у досліджених пацієнтів у динаміці дозволив встановити поступове зростання рівня депресивних проявів як в цілому, так і в розрізі окремих видів депресії. Загальний показник виразності депресії за шкалою M. Hamilton при першому дослідженні у всіх пацієнтів склав $(18,5 \pm 2,1)$ балів (у чоловіків $(19,0 \pm 2,0)$ балів, у жінок $(17,0 \pm 1,3)$ балів, p<0,01), при другому обстеженні - $(24,2 \pm 3,7)$ балів $((24,8 \pm 3,9)$ балів та $(22,4 \pm 2,7)$ балів, p>0,05), при третьому обстеженні - $(30,6 \pm 7,0)$ балів $((31,6 \pm$ $7,3)$ балів та $(27,3 \pm 4,8)$ балів, $p>0,05)$; показник адинамічної депресії - відповідно $(12,6 \pm 2,4)$ балів (у чоловіків $(13,2 \pm 2,2)$ балів, у жінок $(10,3 \pm 1,7)$ балів, p $<0,01)$, при другому обстеженні - $(14,9 \pm 4,6)$ балів $((15,6 \pm 4,4)$ балів та $(12,3 \pm 4,3)$ балів, $p<0,05)$, при

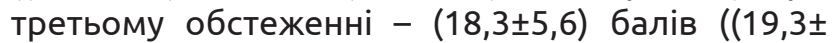
$5,4)$ балів та $(15,0 \pm 5,3)$ балів, $p<0,05)$; показник ажитованої депресії - відповідно $(6,1 \pm 1,7)$ балів (у чоловіків $(6,2 \pm 1,7)$ балів, у жінок $(5,5 \pm 1,4)$ балів, p>0,05), при другому обстеженні - $(7,1 \pm 2,1)$ балів $((7,3 \pm 2,1)$ балів та $(6,6 \pm 1,9)$ балів, $p>0,05)$, при третьому обстеженні - $(6,9 \pm 1,7)$ балів $((7,0 \pm 1,8)$ балів та $(6,5 \pm 1,6)$ балів, p>0,05); депресії зі страхом - відповідно $(7,2 \pm 1,9)$ балів (у чоловіків $(7,6 \pm 1,8)$ балів, у жінок $(5,8 \pm 1,2)$ балів, $p<0,05)$, при другому о6стеженні - $(8,4 \pm 2,4)$ балів $((8,8 \pm 2,4)$ балів та $(6,7 \pm 1,5)$ балів, $p<0,01)$, при третьому обстеженні $(7,2 \pm 2,1)$ балів $((7,6 \pm 2,1)$ балів та $(5,7 \pm 1,5)$ балів, $\mathrm{p}<0,01)$; показник недиференційованої депресії відповідно $(5,6 \pm 1,5)$ балів (у чоловіків $(5,8 \pm 1,5)$ балів, у жінок $(4,9 \pm 1,4)$ балів, p>0,05), при другому обстеженні - $(6,2 \pm 1,9)$ балів $((6,5 \pm 1,9)$ балів та $(5,2 \pm 1,7)$ балів, p>0,05), при третьому обстеженні $(6,9 \pm 2,0)$ балів $((6,7 \pm 2,1)$ балів та $(6,0 \pm 2,2)$ балів, p>0,05). Розбіжності у показниках депресії між першим і другим, першим і третім, другим і третім обстеженнями статистично значущі $(p<0,01)$. 3 наведених даних видно, що у чоловіків значуще вищими при першому обстеженні виявилися загальний показник депресії, а також показники адинамічної депресії і депресії зі страхом; в подальшому відмінності у загальному рівні депресії зменшуються і при другому і третьому обстеженнях стають статистично незначущими $(p>0,05)$.

Аналогічні закономірності були притаманні проявам тривоги. Зокрема, загальний показник тривоги за шкалою M. Hamilton при першому дослідженні у всіх пацієнтів склав $(23,4 \pm 4,9)$ балів (у чоловіків $(24,1 \pm 5,2)$ балів, у жінок $(21,2 \pm 3,5)$ балів, p $>0,05)$, при другому обстеженні - $(26,7 \pm 5,7)$ балів $((27,4 \pm 5,8)$ балів та $(24,4 \pm 4,7)$ балів, p>0,05), при третьому обстеженні - $(23,5 \pm 5,0)$ балів $((24,1 \pm$
$5,1)$ балів та $(21,5 \pm 4,1)$ балів, p>0,05); показник психічної тривоги - відповідно $(15,8 \pm 2,9)$ балів (у чоловіків $(16,1 \pm 3,0)$ балів, у жінок $(15,0 \pm 2,3)$ балів, p>0,05), при другому обстеженні - відповідно $(17,8 \pm 3,4)$ балів $((18,0 \pm 3,5)$ балів та $(16,9 \pm 3,1)$ балів, р>0,05), при третьому обстеженні - відповідно $(16,4 \pm 3,1)$ балів $((16,6 \pm 3,1)$ балів та $(15,7 \pm 2,8)$ балів, p>0,05); показник соматичної тривоги - відповідно $(8,0 \pm 3,8)$ балів (у чоловіків $(8,6 \pm 3,8)$ балів, у жінок $(6,2 \pm 2,9)$ балів, $p<0,05)$, при другому обстеженні - $(9,2 \pm 4,3)$ балів $((9,8 \pm 4,4)$ балів та $(7,2 \pm 3,5)$ балів, p>0,05), при третьому обстеженні $-(8,4 \pm 4,0)$ балів $((9,0 \pm 4,1)$ балів та $(6,5 \pm 3,1)$ балів, $p>0,05)$. Розбіжності у показниках тривоги між першим і другим, першим і третім, другим і третім обстеженнями статистично значущі $(p<0,01)$. У чоловіків показники тривоги $\epsilon$ дещо більшими, ніж у жінок, але статистично значущими ці розбіжності $\epsilon$ лише для соматичної тривоги при першому обстеженні.

Динаміка реактивної тривожності після травматичного ушкодження органа зору відрізняється тенденцією до високого рівня, збільшенням її протягом перших трьох місяців після травми і поступовим зниженням у віддаленому періоді (понад 12 місяців). Показник реактивної тривожності у всіх пацієнтів при першому обстеженні склав $(46,1 \pm 10,7)$ балів (чоловіки $(47,8 \pm 10,9)$ балів, жінки $(40,4 \pm 8,2)$ балів, $p<0,05)$, при другому обстеженні відповідно $(48,5 \pm 12,0)$ балів $((50,3 \pm 12,0)$ балів та $(42,5 \pm 10,3)$ балів, p>0,05), при третьому обстеженні відповідно $(41,0 \pm 10,1)$ балів $((42,6 \pm 10,1)$ балів та $(35,8 \pm 8,7)$ балів, $p<0,05)$. На нашу думку, така динаміка показників реактивної тривожності відображає поступову адаптацію пацієнтів до втрати зору і $\epsilon$ цілком закономірною.

Натомість, рівень особистісної тривожності $з$ часом зростає; найбільше зростання відмічається у період з 3 до 12 місяців після травми. Так, рівень особистісної тривожності увсіх пацієнтів при першому обстеженні склав $(43,3 \pm 11,4)$ балів (чоловіки $(45,2 \pm 11,6)$ балів, жінки $(36,6 \pm 8,1)$ балів, $p<0,05)$, при другому обстеженні - відповідно $(47,6 \pm 12,5)$ балів $((49,8 \pm 12,7)$ балів та $(40,4 \pm 8,8)$ балів, $p<0,05)$, при третьому обстеженні - відповідно $(54,6 \pm$ $14,3)$ балів $((57,1 \pm 14,5)$ балів та $(46,3 \pm 10,2)$ балів, $\mathrm{p}<0,05)$. Така динаміка, ймовірно, відображує формування стійких патохарактерологічних рис, асоційованих зі незворотним погіршенням зору, зокрема, особистісної тривожності.

Аналіз особливостей психопатологічної симптоматики за даними опитувальника SCL-90-R дозволив виявити ряд закономірностей (табл. 1).

Як видно з даних, наведених у таблиці 1, у гострий та віддалений періоди після травматичної втрати зору спостерігається зростання показників соматизації, обсесивно-компульсивної симптома- 
Огляди літератури, оригінальні дослідження, погляд на проблему, випадок з практики, короткі повідомлення Таблиця 1. Середні показники виразності психопатологічної симптоматики за даними опитувальника SCL-90-R у динаміці спостереження

\begin{tabular}{|c|c|c|c|c|c|c|c|c|}
\hline \multirow[b]{2}{*}{ Показник } & \multicolumn{4}{|c|}{1 обстеження } & \multicolumn{4}{|c|}{2 обстеження } \\
\hline & 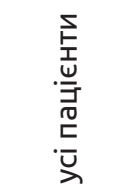 & 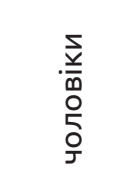 & $\cdot \frac{\overrightarrow{\underline{v}}}{\overrightarrow{\underline{x}}}$ & $P$ & 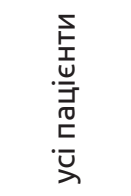 & 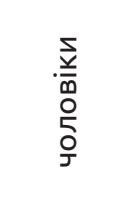 & $\cdot \frac{\vec{z}}{\vec{x}}$ & $p$ \\
\hline Соматизація & $1,1 \pm 0,9$ & $1,2 \pm 0,9$ & $0,9 \pm 0,7$ & $>0,05$ & $1,3 \pm 1,0$ & $1,4 \pm 1,1$ & $1,1 \pm 0,8$ & $>0,05$ \\
\hline $\begin{array}{l}\text { Обсесивно-компульсивні } \\
\text { розлади }\end{array}$ & $1,4 \pm 0,6$ & $1,5 \pm 0,6$ & $1,2 \pm 0,5$ & $>0,05$ & $1,7 \pm 0,7$ & $1,8 \pm 0,7$ & $1,4 \pm 0,6$ & $>0,05$ \\
\hline Міжособистісна сенситивність & $1,0 \pm 0,5$ & $1,0 \pm 0,5$ & $0,8 \pm 0,4$ & $<0,05$ & $1,2 \pm 0,6$ & $1,3 \pm 0,6$ & $0,9 \pm 0,5$ & $<0,05$ \\
\hline Депресія & $1,9 \pm 0,5$ & $2,0 \pm 0,5$ & $1,7 \pm 0,4$ & $<0,05$ & $2,3 \pm 0,6$ & $2,4 \pm 0,6$ & $2,0 \pm 0,5$ & $<0,05$ \\
\hline Тривожність & $2,5 \pm 0,5$ & $2,5 \pm 0,5$ & $2,4 \pm 0,6$ & $>0,05$ & $2,9 \pm 0,6$ & $2,9 \pm 0,6$ & $2,7 \pm 0,6$ & $>0,05$ \\
\hline Ворожість & $1,1 \pm 0,4$ & $1,1 \pm 0,4$ & $1,0 \pm 0,5$ & $>0,05$ & $1,1 \pm 0,4$ & $1,1 \pm 0,4$ & $1,0 \pm 0,5$ & $>0,05$ \\
\hline Фобічна тривожність & $1,1 \pm 0,8$ & $1,2 \pm 0,8$ & $0,9 \pm 0,8$ & $>0,05$ & $1,3 \pm 1,0$ & $1,4 \pm 1,0$ & $1,0 \pm 0,9$ & $>0,05$ \\
\hline Паранояльні симптоми & $0,2 \pm 0,2$ & $0,2 \pm 0,2$ & $0,1 \pm 0,1$ & $>0,05$ & $0,2 \pm 0,2$ & $0,2 \pm 0,2$ & $0,1 \pm 0,2$ & $>0,05$ \\
\hline Психотизм & $0,1 \pm 0,1$ & $0,1 \pm 0,2$ & $0,1 \pm 0,1$ & $>0,05$ & $0,1 \pm 0,2$ & $0,1 \pm 0,2$ & $0,1 \pm 0,1$ & $>0,05$ \\
\hline \multirow{2}{*}{\multicolumn{2}{|c|}{ Показник }} & \multicolumn{4}{|c|}{3 обстеження } & \multicolumn{3}{|c|}{$\begin{array}{c}\text { р при порівнянні чоловіків } \\
\text { і жінок }\end{array}$} \\
\hline & &  & 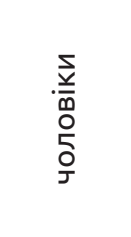 & $\stackrel{\overrightarrow{\underline{v}}}{\cdot \vec{x}}$ & $p$ & 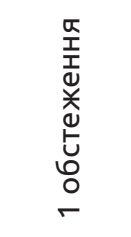 & 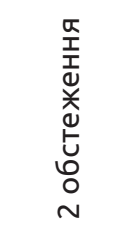 & 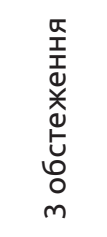 \\
\hline \multicolumn{2}{|l|}{ Соматизація } & $1,4 \pm 1,1$ & $1,5 \pm 1,2$ & $1,2 \pm 0,8$ & $>0,05$ & $>0,05$ & $>0,05$ & $>0,05$ \\
\hline \multicolumn{2}{|l|}{ Обсесивно-компульсивні розлади } & $1,9 \pm 0,8$ & $2,0 \pm 0,8$ & $1,6 \pm 0,7$ & $>0,05$ & $>0,05$ & $>0,05$ & $>0,05$ \\
\hline \multicolumn{2}{|l|}{ Міжособистісна сенситивність } & $1,6 \pm 0,8$ & $1,8 \pm 0,8$ & $1,3 \pm 0,7$ & $<0,05$ & $<0,05$ & $<0,05$ & $<0,05$ \\
\hline \multicolumn{2}{|l|}{ Депресія } & $3,0 \pm 0,8$ & $3,1 \pm 0,8$ & $2,6 \pm 0,6$ & $<0,05$ & $<0,05$ & $<0,05$ & $<0,05$ \\
\hline \multicolumn{2}{|l|}{ Тривожність } & $2,6 \pm 0,6$ & $2,7 \pm 0,6$ & $2,5 \pm 0,6$ & $>0,05$ & $>0,05$ & $>0,05$ & $>0,05$ \\
\hline \multicolumn{2}{|l|}{ Ворожість } & $1,3 \pm 0,5$ & $1,4 \pm 0,5$ & $1,3 \pm 0,6$ & $>0,05$ & $>0,05$ & $>0,05$ & $>0,05$ \\
\hline \multicolumn{2}{|l|}{ Фобічна тривожність } & $1,5 \pm 1,1$ & $1,6 \pm 1,1$ & $1,1 \pm 1,0$ & $>0,05$ & $>0,05$ & $>0,05$ & $>0,05$ \\
\hline \multicolumn{2}{|l|}{ Паранояльні симптоми } & $0,2 \pm 0,2$ & $0,2 \pm 0,2$ & $0,1 \pm 0,2$ & $>0,05$ & $>0,05$ & $>0,05$ & $>0,05$ \\
\hline \multicolumn{2}{|l|}{ Психотизм } & $0,1 \pm 0,2$ & $0,1 \pm 0,2$ & $0,1 \pm 0,1$ & $>0,05$ & $>0,05$ & $>0,05$ & $>0,05$ \\
\hline
\end{tabular}

тики, міжособистісної сенситивності, депресії, тривожності, ворожості та фобічної тривожності; при цьому розбіжності при порівнянні зазначених показників при першому і другому, другому і третьому, першому і третьому обстеженнях статистично значущі $(p<0,01)$. У чоловіків показники вищі, ніж у жінок, однак статистично значущими ці відмінності $\epsilon$ лише для міжособистісної сенситивності і депресії. Щодо паранояльних симптомів і психотизму, то ця сипмтоматика не $\epsilon$ типовою для дослідженого контингенту і не зазнає змін у динаміці.

Одержані нами дані узгоджуються з даними як більш ранніх власних досліджень, так і досліджень інших авторів щодо основних психопатологічних феноменів, асоційованих з травматич- ною втратою зору, зокрема, з домінуванням у психопатологічній картині проявів депресії і тривоги. У нашому дослідженні також знайшли підтвердження наукові дані інших дослідників щодо формування у осіб з втратою зору стійких патохарактерологічних змін і розладів непсихотичного регістру. Водночас ми отримали нові, розширені дані щодо спектра і виразності окремих психопатологічних проявів, асоційованих з втратою зору, у гендерному аспекті.

Дані дослідження можуть бути використані при розробці лікувально-реабілітаційних заходів для осіб із втратою зору, а також для планування профілактичних заходів для цього контингенту пацієнтів. 
Огляди літератури, оригінальні дослідження, погляд на проблему, випадок з практики, короткі повідомлення

Висновки. 1. Тяжка втрата зору травматичного ґенезу супроводжується несприятливими психопатологічними порушеннями, найактуальнішими з яких є депресивні й тривожні прояви.

2. Після травматичного пошкодження зору тяжкого ступеня виразність психопатологічних феноменів поступово наростає; при цьому депресивні прояви характеризуються більш рівномірним темпом зростання, тоді як прояви реактивної тривожності, після зростання у перші місяці після травми, у подальшому, в період понад 12 місяців, зменшуються, при паралельному зростанні показників особистісної тривожності, що відображає формування стійких патохарактерологічних змін.

3. Тяжкість усіх психопатологічних проявів, асоційованих з травматичним ушкодженням органа зору тяжкого ступеня, у чоловіків є більшою,

\section{ЛІТЕРАТУРА}

1. Mohseni M. Blunt Eye Trauma / M. Mohseni, B. N. Bragg // Stat Pearls Publishing. - 2019. - P. 2-12.

2. Visual and ocular morbidity in severe open-globe injuries presenting to a regional eye centre in New Zealand / J. H. Court, L. M. Lu, N. Wang, C. N. J. McGhee // Clinical and Experimental Ophthalmology. - 2019. - Vol. 47 (4). P. 469-477.

3. Seasonal distribution of ocular conditions treated at the emergency room: a 1-year prospective study / E. Sen, S. Celik, M. Inanc [et al.] // Arq. Bras. Oftalmol. - 2018. Vol. 81 (2). - P. 116-119.

4. Blindness and vision impairment. Information Bulletin. WHO. Geneva, 2018.

5. Vision-Specific Distress and Depressive Symptoms in People with Vision Impairment / G. Rees, H. W. Tee, M. Marella [et al.] // Invest. Ophthalmol. Vis. Sci. - 2010. Vol. 51 (6). - P. 2891-2896.

6. Psychological well-being and quality of life in visually impaired baseball players / D. Mirandola, M. Monaci, G. Miccinesi [et al.] // PloS One. - 2019. - Vol. 14 (6). - P. 18-24.

\section{REFERENCES}

1. Mohseni, M., \& Bragg, B.N. (2019). Blunt Eye Trauma. Stat Pearls Publishing, 2-12.

2. Court, J.H., Lu, L.M., Wang, N., \& McGhee C.N.J. (2019). Visual and ocular morbidity in severe open-globe injuries presenting to a regional eye centre in New Zealand. Clinical and Experimental Ophthalmology, 47 (4), 469-477.

3. Sen, E., Celik, S., Inanc, M., Elgin, U., Ozyurt, B, \& Yılmazbas P. (2018). Seasonal distribution of ocular conditions treated at the emergency room: a 1-year prospective study. Arq. Bras. Oftalmol., 81 (2), 116-119.

4. WHO. Geneva. (2018). Blindness and vision impairment. Information Bulletin.

5. Rees, G., Tee, H.W., Marella, M. Fenwick, E., Dirani, M., \& Lamoureux, E.L. (2010). Vision-specific distress ніж у жінок, проте значущими ці відмінності $\epsilon$ лише для окремих депресивних і тривожних феноменів, а також для міжособистісної сенситивності.

4. Особливості клінічної феноменології та динаміки психопатологічних змін при травматичному ушкодженні органа зору тяжкого ступеня слід враховувати при розробці диференційованих лікувальних, реабілітаційних та профілактичних заходів.

Перспективи подальших досліджень пов'язані із більш детальним вивченням особливостей психопатологічних проявів при різних варіантах пошкодження органа зору, а також полягають у розробці на підставі даних цих досліджень персоніфікованих лікувально-профілактичних та реабілітаційних заходів.

7. Абдряхимова Ц. Б. Взаимосвязь клинико-психопатологических проявлений непсихотических психических расстройств и стратегий преодоления у лиц с частичной потерей зрения травматического генеза / Ц. Б. Абдряхимова // Український вісник психоневрології. - 2014. - Т. 23, Вип. 1 (78). - С. 54-57.

8. Hamilton M. A. A rating scale for depression by Max Hamilton / M. A. Hamilton // Journal of Neurology, Neurosurgery, Psychiatry. - 1960. - No. 23. - P. 56-62.

9. Hamilton M. The assessment of anxiety states by rating / M. Hamilton // British Journal of Medical Psychology. - 1959. - No. 32. - P. 50-55.

10. Психология личности: тесты, опросники, методики / сост. Н. В. Киршева, Н. В. Рябчикова. - М. : Геликон, 1995. - С. 71-74.

11. Тарабрина Н. В. Практикум по психологии посттравматического стресса / Н. В. Тарабрина. - СПб. : Питер, 2001. - С. 146-181.

and depressive symptoms in people with vision impairment. Invest. Ophthalmol. Vis. Sci., 51 (6), 2891-2896.

6. Mirandola, D., Monaci, M., Miccinesi, G., Vannuzzi, A., Sgambati, E., Manetti, M., \& Marini M. (2019). Psychological well-being and quality of life in visually impaired baseball players. Plos One., 14 (6), 18-24.

7. Abdriakhimova, T.B. (2014). Vzaimosvyaz kliniko-psihopatologicheskikh proyavleniy nepsihotisheskikh rasstroystv i strategiy preodoleniya u lits s chastichnoy poterey zreniya travmaticheskogo geneza [Clinical relationship psychopathology nonpsychotic mental disorders and strategies for overcoming patients partially sighted traumatic genesis]. Ukrainain Gazette of Psychoneurology, 23, 1 (78), 54-57 [in Russian]. 
Огляди літератури, оригінальні дослідження, погляд на проблему, випадок з практики, короткі повідомлення

8. Hamilton, M.A. (1960). A rating scale for depression by Max Hamilton. Journal of Neurology, Neurosurgery, Psychiatry, 23, 56-62.

9. Hamilton, M. (1959). The assessment of anxiety states by rating. British Journal of Medical Psychology, 32, 50-55.

10. Kirsheva, N.V., \& Ryabchikova, N.V. (Eds.). (1995).
Psihologiya lichnosti: testy, oprosniki, metodiki [Personality psychology: tests, questionnaires, methodologies]. Moscow, Helikon, 71-74.

11. Tarabrina, N.V. (2001). Praktikum po psihologii posttravmaticheskogo stressa [Workshop on the psychology of posttraumatic stress]. Saint-Petersburg: Piter [in Russian].

\title{
КЛИНИКО-ПСИХОПАТОЛОГИЧЕСКИЕ ОСОБЕННОСТИ ПАЦИЕНТОВ С ТРАВМАТИЧЕСКИМ ПОВРЕЖДЕНИЕМ ОРГАНА ЗРЕНИЯ
}

\author{
ФН. Г. Пшук, А. А. Белов, Н. Г. Мацько \\ Винницкий национальный медицинский университет имени Н. И. Пирогова
}

РЕЗЮМЕ. Проблема потери зрения является одной из актуальных медицинских и социальных проблем.

Цель - изучить особенности клинико-психопатологических проявлений, ассоциированных со значительным ухудшением зрения вследствие травматического повреждения зрительного анализатора.

Материал и методы. Исследованы особенности психопатологической симптоматики у 37 мужчин и 11 женщин со значительной потерей зрения вследствие травматического повреждения в динамике в первые две недели с момента травмы, через 3 месяца и через 12 месяцев после травмы с использованием шкал депрессии и тревоги M. Hamilton, шкал реактивной и личностной тревожности C. Spilberger и опросника SCL-90-R.

Результаты. Установлен постепенный значимый $(p<0,01)$ рост уровня депрессивных проявлений в динамике

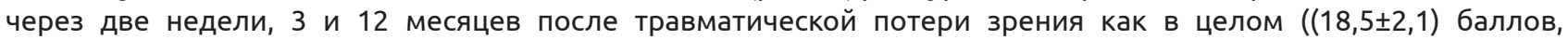
$(24,2 \pm 3,7)$ баллов, $(30,6 \pm 7,0)$ баллов), так и в разрезе отдельных видов депрессии; а также тревоги в целом $((23,4 \pm 4,9)$ баллов, $(26,7 \pm 5,7)$ баллов, $(23,5 \pm 5,0)$ баллов), психической и соматической тревоги.

Реактивная тревожность высока после травмы, и возрастает в течение первых трех месяцев после нее, постепенно снижаясь в дальнейшем $((46,1 \pm 10,7)$ баллов, $(48,5 \pm 12,0)$ баллов, $(41,0 \pm 10,1)$ баллов). Уровень личност-

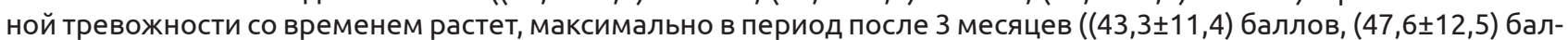
лов, $(54,6 \pm 14,3)$ баллов), отражая формирование устойчивых патохарактерологических черт.

В острый и отдаленный периоды после травматической потери зрения наблюдается значимый рост показателей соматизации, обсессивно-компульсивной симптоматики, межличностной сенситивности, депрессии, тревожности, враждебности и фобической тревожности $(p<0,01)$. У мужчин показатели выше, чем у женщин, однако, статистически значимы эти различия лишь для межличностной сенситивности и депрессии.

Выводы. Тяжелая потеря зрения травматического генеза сопровождается неблагоприятными психопатологическими нарушениями, прежде всего депрессивными и тревожными; выраженность психопатологических феноменов постепенно нарастает после травмы. Тяжесть всех психопатологических проявлений, ассоциированных с травматическим повреждением зрения тяжелой степени, у мужчин больше, по сравнению с женщинами.

КЛючЕВЫЕ СЛОВА: травматическая потеря зрения; клинико-психопатологическая феноменология.

\section{CLINICAL AND PSYCHOLOGICAL FEATURES OF PATIENTS WITH TRAUMATIC INJURY OF THE EYE}

\author{
@N. G. Pshuk, O. O. Belov, N. G. Matsko \\ M. Pyrohov Vinnytsia National Medical University
}

SUMMARY. The problem of vision loss is one of the actual medical and social problems.

The aim of the study - to investigate the features of clinical and psychopathological manifestations associated with significant impairment of vision due to traumatic damage to the visual analyzer.

Material and Methods. We have studied the features of psychopathological symptomatology in 37 men and 11 women, with significant loss of vision due to traumatic injury in the dynamics in the first two weeks after trauma, 3 months, and 12 months after trauma using the M. Hamilton Depression and Anxiety Scales, and C. Spilberger's personal anxiety and the SCL-90-R questionnaire.

Results and Discussion. A gradual significant $(p<0.01)$ increase in the level of depressive manifestations in the dynamics was found two weeks, 3 and 12 months after traumatic vision loss as a whole (18.5 \pm 2.1$)$ points, (24.2 \pm 3.7$)$ points, (30.6 \pm 7.0$)$ points) and in terms of particular types of depression; as well as anxiety in general (23.4 \pm 4.9$)$ points, (26.7 \pm 5.7$)$ points, $(23.5 \pm 5.0)$ points), as well as mental and somatic anxiety.

Reactive anxiety is high after trauma, increases during the first three months after trauma, and gradually decreases thereafter $(46.1 \pm 10.7)$ points, $(48.5 \pm 12.0)$ points, $(41.0 \pm 10.1)$ points). The level of personal anxiety increases over time, 
Огляди літератури, оригінальні дослідження, погляд на проблему, випадок з практики, короткі повідомлення maximum after 3 months (43.3 \pm 11.4$)$ points, $(47.6 \pm 12.5)$ points, $(54.6 \pm 14.3)$ points), reflecting the formation of persistent pathocharacterological features.

In acute and distant periods after traumatic vision loss, there is a significant increase in somatization, obsessivecompulsive symptoms, interpersonal sensitivity, depression, anxiety, hostility and phobic anxiety $(p<0.01)$. In men, rates are higher than in women, however, statistically significant these differences are only for interpersonal sensitivity and depression.

Conclusions. The severe loss of vision of traumatic genesis is accompanied by adverse psychopathological disorders, first of all, depressive and anxiety; expressiveness of psychopathological phenomena gradually increases after trauma. The severity of all psychopathological manifestations associated with severe traumatic visual impairment in men is greater than in women.

KEY WORDS: traumatic injury of the eye; clinical psychopathological phenomenology.

Отримано 24.08.2019 